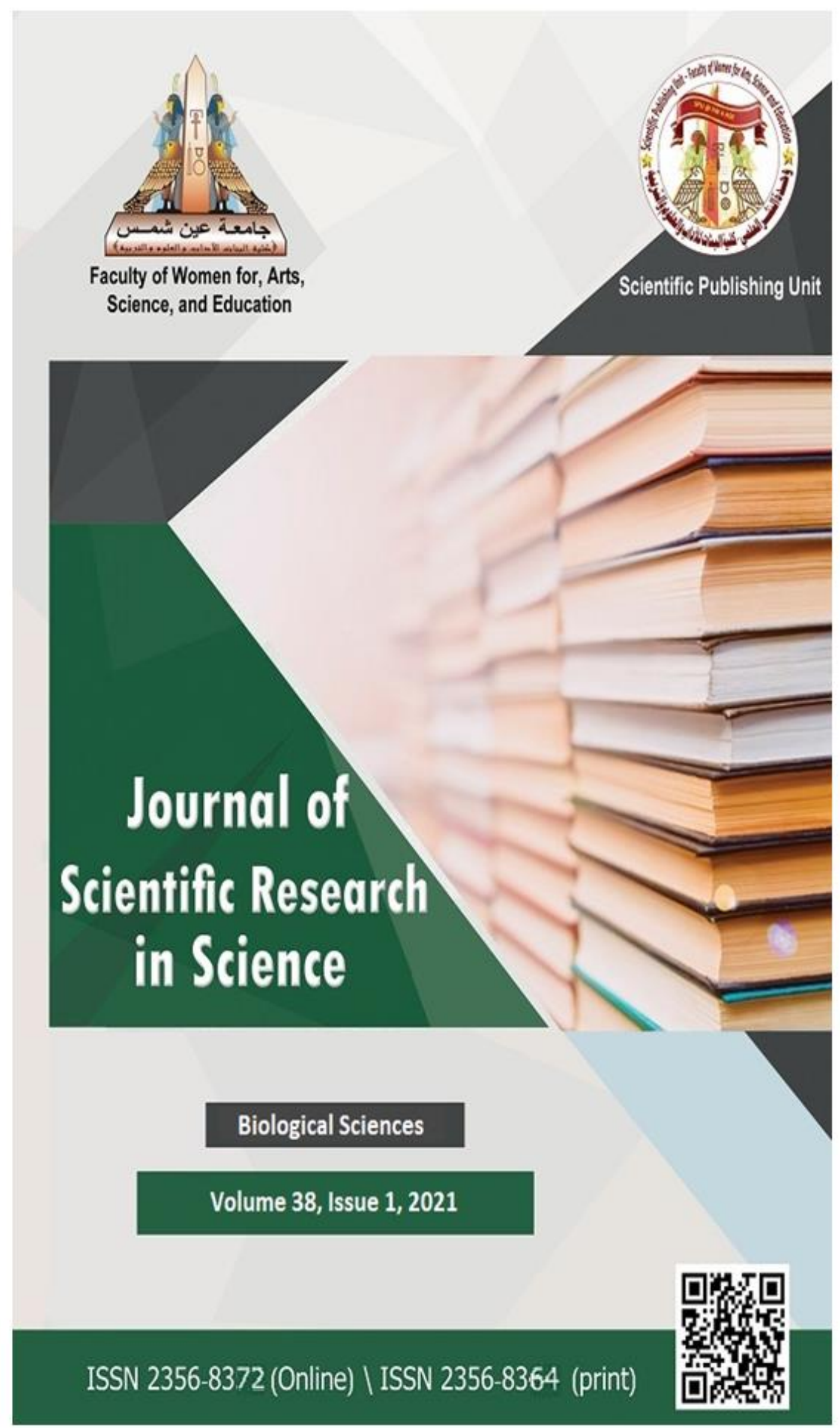




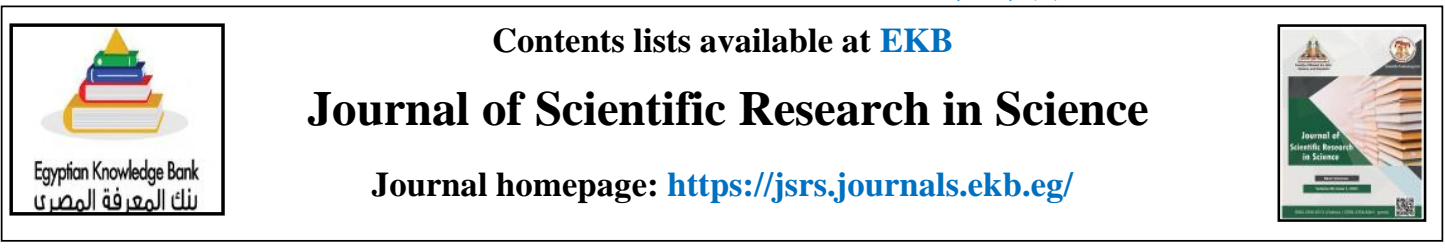

\title{
Efficiency of transgenic Chlamydomonas reinhardtii for removing of toxicity of cyanide compound.
}

\author{
Rasha Abed ELgammal ${ }^{1, *}$, Yassin Mahmoud El-Ayouty ${ }^{2}$, Shaimaa Selmi \\ Sobieh$^{1}$, Wafaa Sobhy Abu EL-Kheir ${ }^{1}$, Alia Anwer EL-Sheimy ${ }^{1}$, Abd EL- Fattah \\ Soror $^{2}$ \\ ${ }^{1}$ Botany Department, Faculty of Women for Arts, Science and Education, Ain-Shams \\ University, Cairo, Egypt. \\ ${ }^{2}$ Botany Department, Faculty of Science, Zagazig, Univeristy, Sharkia, Egypt.
}

\begin{abstract}
In this study, we used the Agrobacterium tumefaciens-mediated transformation approach to transfer the activity of the cyanobacterial cyanase enzyme into the microalga, Chlamydomonas reinhardtii. In transgenic $C$. reinhardtii strains, the recombinant cyanase enzyme was proven to be active. In comparison to wild-type control, transgenic type demonstrated higher rates of ammonia release, reduced loss of pigmentation, and a lower percentage of growth retardation when varied amounts of cyanide (up to $200 \mathrm{ppm}$ ) were applied to the growth medium. Moreover, cyanase activity increases as concentration of cyanide increase especially in case of transgenic. The maximum activity was indicated in presence of $100 \mathrm{mg} / \mathrm{l}$ cyanide it reached eight folds more than wild activity at the same cyanide concentration. Results of this study provide an effective eco-friendly phytoremediation system for detoxification of cyanide using micro-alga compared to previously reported conventional system for removal of cyanide compounds, Also, some factors are taken in consideration like different $\mathrm{pH}$, contact time and the transgenic type has been the priority for removal cyanide at wide range of $\mathrm{pH}$ with two folds more than wild type.
\end{abstract}

Keywords: Cyanide; Phytoremediation; Transgenic and Chlamydomonas reinhardtii.

\section{Introduction}

The $\mathrm{C} \equiv \mathrm{N}$ group is found in cyanide compounds. It can be found all throughout the environment. Many different kinds of species dissolved in water are found in varied physical forms. Cyanide is a very poisonous compound that is released into the environment by many industries such as coal cooking, metal plating, electronics, mining, electroplating, steel tempering, photography, acrylic plastics synthesis, drugs, dyes, plastics, and organic chemical manufacturing [1-7].

*Corresponding author: Rasha Abed Elgammal, Botany Department, Faculty of Women for Arts, Science and Education, Ain-Shams University, Cairo, Egypt.

Email: rasha.abed@women.asu.edu.eg 
Cyanide has a high toxicity because it can disrupt respiratory system, due to its binding to cytochrome $\mathrm{C}$ oxidase [8]. In this process, electron transport chain seized the cyanide binding with the iron ion in terminal electron acceptor in cytochrome $\mathrm{C}$ oxidase leading to rapid declining respiration rates and inhibit ATP synthesis in mitochondria [9]. Small amounts of cyanide exposure can be deadly [10-13].

Water containing cyanide must be trearted before being discharged into the environment to safeguard the environment and water bodies. There are several conventional methods used in treating effluents containing cyanide before discharging it into the environment. The most common ones are the alkaline chlorination, sulfur oxide/air process and hydrogen peroxide process [12,14]. However, the used chemicals are hazardous since, the reagents create additional toxicity to biological ecosystem and these methods are expensive.

Various food crop, forage, and horticulture plants produce cyanogenic glucosides, which stored in vacuoles of plant and released as a nitrogen source when plant tissues are damaged. Some plant and algae such as Cyanobacteria, Chlorella vulgaris, Scendesmus, and Nostoc muscorum produce HCN as a defence mechanism against herbs [15]. Fungi like Actinomycetes and Tricholoma and bacteria like certain Pseudomonas species, Chromobacterium violaceum produce and metabolize cyanide [16].

The enzyme cyanidase (cyanide dihydratase) is primarily found in bacteria. Cyanide dihydratase and cyanide hydratase have similarity at both the amino acid and structural levels to nitrilase and nitrile hydratase enzymes [17].

Five general pathways as reported in literature for the biodegradation of cyanide, these are: hydrolytic pathway, oxidative pathway, reductive pathway, substitution/transfer pathway, and syntheses pathway [18]. First three pathways are degradation pathways in which enzymes catalyze the conversion of cyanides into simple organic or inorganic molecules and converts it to ammonia, methane, $\mathrm{CO}_{2}$, formic acid, and carboxylic acid. Last two pathways are for the assimilation of cyanide in the microbe as nitrogen and carbon source [2].

The oxidative reactions for the biodegradation of cyanide form ammonia and carbon dioxide. Cyanide monoxygenase converts cyanide to canate, which canase then catalyzing the bicarbonate- dependent conversion of cyanate to ammonia and 
carbon dioxide [19]. A second oxidative pathway utilizes cyanide dioxygenase to form carbon dioxide and ammonia directly. Cyanide detoxification by algae has been shown in only a few studies [20]. Several algae can effectively degrade cyanide as nitrogen and/or carbon source for their growth. Cyanide effluent degradation by Scendesmus obliqus has been examined [21].

Various parameters, such as the initial concentration of cyanide, initial cell density, and time, all had a substantial impact on cyanide detoxification by algae. Few microbes, such as the bacteria Klebsiella oxytoca, may use cyanide compounds as nitrogen and carbon sources to fuel their own growth. Despite cyanide compounds are very toxic, biological treatments are viable alternatives to chemical procedures without or adding new hazardous chemicals [3, 22-24]. This works aims to elevate the rate of cyanide removal via transformed micro green alga with parallel comparison with the wild efficiency as an alternative method for bioremediation of cyanide.

\section{Materials and methods}

\subsection{Materials}

Prof. Dr. Mohammed Ismaeil, Faculty of Sciense, Mansoura University, Egypt, generously provided Chlamydomonas reinhardtii P.A.Dangeard strains CC$124\left(\mathrm{mt}^{-}\right)$.

Prof. Dr. Yassin EL-Ayouty, Faculty of Science, Zagazig Univeristy, Egypt, generously provided transgenic genotype.

\section{.Chlamydomonas reinhardtii culture conditions:}

Transformation was carried out according to [25]. C. reinharditii was cultivated according to [26]. Solid Tris Acetate Phosphate (TAP) medium supplemented with 1.5 percent (w/v) agar and kanamycin $(50 \mu \mathrm{g} / \mathrm{ml})$ was used to select transformed C.reinhardtii colonies. The algal cultures were incubated in growth chamber at $25{ }^{\circ} \mathrm{C}$ and kept under light intensity $80 \mu \mathrm{mol} \mathrm{m} \mathrm{m}^{-2} \mathrm{~s}^{-1}$ with continuous shaking at $150 \mathrm{rpm}$ in case of liquid cultures. The well-developed colonies in presence of kanamycin were selected and inoculated in sterile fresh TAP medium and allowed to grow under the previous condition of growth. The growing cultures were used for the following experiments. 


\subsection{Methods}

\subsubsection{Growth Assays of both genotypes under cyanide stress}

Similar amounts of wild-type, Chlamydomonas reinhardtii CYN-1, Chlamydomonas reinhardtii CYN-2 cells have been inoculated into liquid TAP media supplemented with $0.0,25,50,100,150$, and $200 \mathrm{mg} / \mathrm{l}$ potassium cyanide and cultivated for 26 days. The densities of algal cells were then measured at $665 \mathrm{~nm}$ [27] at regular interval periods (48 h). Mid log phase was estimated.

\subsubsection{Cyanide degrading experiment}

Distinct healthy green algal cells of Chlamydomonas reinhartdii were used as inoculum for the different flasks containing $50 \mathrm{ml}$ sterilized TAP medium. The different flasks comprise six group, three flasks for each concentration were prepared. The first group devoid cyanide (control), whereas the others having 25, 50, 100, 150 and $200 \mathrm{mg} / \mathrm{l}$ potassium cyanide. All the flasks were inoculated with $5 \mathrm{mls}$ of healthy algae under aseptic conditions. ( $1 \mathrm{ml}=0.6$ optical density) and incubated for 72 hours under light intensity $80 \mu \mathrm{mol} \mathrm{m} \mathrm{m}^{-2} \mathrm{~s}^{-1}$ at $25{ }^{\circ} \mathrm{C}$. For determination of $\mathrm{KCN}$ residu a volume of $5 \mathrm{ml}$ was taken from each group at different times (zero time, $6 \mathrm{~h}, 12 \mathrm{~h}, 24$ h, $36 \mathrm{~h}, 48 \mathrm{~h}$, and $72 \mathrm{~h}$ ) for spectrophotometric estimation by isonicotinic acidpyrazolone. It was measured at $638 \mathrm{~nm}$ by ultraviolet-visible spectrophotometer (YQ00302), according to [28] at regular intervals.

Amount of cyanide removal was calculated as follow:

Amount of cyanide removal $(\mathrm{mg} / \mathrm{l})=\mathrm{C}_{0}-\mathrm{C}_{\mathrm{r}}$

Where $\mathrm{C}_{0}$ is the initial concentration of cyanide $(\mathrm{mg} / \mathrm{l})$

and $\mathrm{C}_{\mathrm{r}}$ is the residual concentration of cyanide $(\mathrm{mg} / \mathrm{l})$.

\subsubsection{Ammonia released by transegenic $C$. reinhardtii under cyanide stress}

The approach reported by [29] with some modifications was used to release ammonia from transgenic $C$. reinhardtii at different potassium cyanide concentrations. For 12 days, transgenic $C$. reinhardtii cells and wild type were grown in liquid TAP media. Algal cells were harvested, and a weight of $0.02 \mathrm{~g}$ of algal cells from each wild type and transgenic type was transferred into 2-ml micro tubes containing $1 \mathrm{ml}$ of incubation medium [potassium phosphate $\mathrm{pH} 5.8(50 \mathrm{mM})$, tween 
$20(1 \%)$, sucrose (2\%), phosphinotricin $(25 \mathrm{mg} / \mathrm{l})$, and 2, 4- dichlorophenoxy acetic acid $\left.\left(0.1 \mathrm{mg} \mathrm{l}^{-1}\right)\right]$ supplemented with 0, 25, 50, 100, 150, and $200 \mathrm{mg} / \mathrm{l} \mathrm{KCN}$. Three reaction micro tubes containing incubation media were used as blanks.Under $80 \mu \mathrm{mol}$ $\mathrm{m}^{-2} \mathrm{~s}^{-1}$ light, the test samples were incubated for 16 hours at $25^{\circ} \mathrm{C}$. A volume of 100 $\mu \mathrm{l}$ of each samples was put into a fresh $1.5-\mathrm{ml}$ reaction tube containing $0.5 \mathrm{ml}$ of reagent-I which consist of [sodium nitroprusside $(0.4 \mathrm{mM})$, sodium salicylate $(0.21$ $\mathrm{M})$, trisodium citrate $(0.085 \mathrm{M})$, and sodium tartrate $(25 \mathrm{~g} / \mathrm{l})$ ] after centrifugation at 13,000 rpm/5 min. Avolume of $500 \mu \mathrm{l}$ of reagent-II which consist of [disodium dichloro isocyanurate $(2.3 \mathrm{mM})$, and $\mathrm{NaOH}(0.75 \mathrm{M})]$ was added to the samples. After that, the reaction mixures were kept in the dark at $37{ }^{\circ} \mathrm{C}$ for 15 minutes before being incubated at room temperature. The absorbance at $655 \mathrm{~nm}$ of the test samples were measured and compared to ammonium chloride standards to determine the amount of ammonium ions present.

\subsubsection{Extraction of protein and cyanase assays}

$100 \mathrm{mg}$ fresh algal tissues from wild-type and transgenic C. reinhardtii cells were frozen in liquid nitrogen. After homogenising the frozen pellets, a volume of $500 \mu$ of extraction buffer were added. The homogenate was centrifuged twice for 20 minutes at $402 \mathrm{xg}$ at $4{ }^{\circ} \mathrm{C}$. The protein concentration in the supernatants was then measured according to [30]. Cyanase activity was evaluated according to the protocol described by [31]. The reaction mixture composed of [potassium phosphate buffer $50 \mathrm{mM}(\mathrm{pH}$ 7.7), $2 \mathrm{mM} \mathrm{NaHCO}$ and $2 \mathrm{mM} \mathrm{KCN}$ ]. The reaction was started by addition of protein extract and stopped by adition of equal volumes of Nessler's reagent after 1-10 min at $26{ }^{\circ} \mathrm{C}$. A standard curve was created using ammonium chloride dilution series. The amount of ammonia released was estimated by measuring the optical density at 420 $\mathrm{nm}$. The activity of cyanase was measured in $\mu \mathrm{mol}$ ammonia released $/ \mathrm{mg}$ protein $/ \mathrm{min}$.

\subsubsection{Extraction and determination of green pigments under cyanide stress}

Green pigments, Cl. a, Cl. b, were extracted from wild-type and transgenic cells grown for 3 days in liquid TAP medium supplemented with different concentration of $\operatorname{KCN}(0.0,25,50,100,150$, and $200 \mathrm{mg} / \mathrm{l})$ by using acetone $80 \%$. The mixture was centrifuged at $402 \mathrm{xg}$ for $10 \mathrm{~min}$ after homogenyiation and vigorous shaking, absorbance of the supernatants was measured at 630, 647, $664 \mathrm{~nm}$. Pigments contents were calculated as described by $[32,33]$. 


\subsubsection{Effeciency of both wild and transgenic genotypes to detoxifying cyanide at different pHs}

In this experiment two sets of $250 \mathrm{ml}$ flasks containing $100 \mathrm{ml}$ sterile TAP medium supplemented with $25 \mathrm{mg} / \mathrm{l}$ of potassium cyanide and different $\mathrm{pH}$ values $(4,5,6,7$, $8,9,10$, and 11) were prepared one set inoculated with $2 \mathrm{ml}$ transgenic cells and the other with wild cells (inocula having $6 * 10^{6}$ cells for each) and cultred for $24 \mathrm{~h}$ (The contact time), all the flasks were kept at $25{ }^{\circ} \mathrm{C}$. At the end of incubation period, centrifugation was carried out and the clear solution was ready to determine the residual of potassium cyanide as previously mentioned to calculate the amount of cyanide removal.

Percentage of cyanide removal $=\left(\mathrm{C}_{0}-\mathrm{C}_{\mathrm{r}}\right) \times 100 / \mathrm{C}_{0}$

Where $\mathrm{C}_{0}$ is the initial concentration of cyanide $(\mathrm{mg} / \mathrm{l})$

and $\mathrm{C}_{\mathrm{r}}$ is the residual concentration of cyanide $(\mathrm{mg} / \mathrm{l})$.

\subsubsection{Statistical analysis}

For each wild type and transgenic type the data was represented in figures as mean \pm standard error (SE). The obtained data were analyzed statistically using SPSS to determine significant differences among the data. Difference was considered significant $(*)$ when $\mathrm{P}<0.05$, highly significant $(* *)$ when $\mathrm{P}<0.01$ and very highly significant $(* * *)$ when $\mathrm{P}<0.001$.

\section{Results and discussion}

\subsection{Growth assays of both genotypes under cyanide stress}

The results of this assay are shown in Fig.1 Both wild type and CYN transgenic lines showed a concentration-dependent inhibition of Chlamydomonas reinhardtii growth. The least reduction in algal growth was indicated following $25 \mathrm{mg}^{-1}$ with speed reference to transgenic type this platoue was changeable to the high reduction in growth especially in case of wild type at $150 \mathrm{mg}^{-1}$ and no growth at $200 \mathrm{mg}^{-1}$ whereas, transgenic grow at $200 \mathrm{mg}^{-1}$ with an obvious decrease due to natural rate of decay as the nutrient consumed. The obvious reduction in wild type growth in prescence of potassium cyanide may be attributed to the inefficient capacity of the endogenous cyanaide metabolizing enzymes to remove the applied cyanide from the growth [25, 34-35]. It is crucial to compare the current CYN growth assay resuls with previously 
published CYN transgenic A. thaliana plant [36]. When cyanate concentration of 2.5 $\mathrm{mM}$ was applied to the foliar parts of the plants, a similar growth retardation effect was observed for wild type Arabidopsis thaliana. In addition, in wild-type Arabidopsis plants, $0.4 \mathrm{mM}$ cyanate in the culture media completely inhibited root hair production. However, expression of the cyanobacterial cyanase enzyme in Arabidopsis thaliana plants improves plant resistance to exogenously cyanate up to $1.2 \mathrm{mM}$ in both growth experiments. Indeed, the enhanced growth of CYN transgenic C. reinhardtii at higher cyanide concentrations (i.e., 100, 150, and $200 \mathrm{mg} / \mathrm{l} \mathrm{KCN}$ ) compared to wild-type cells suggests the usage of CYN transgenic C. reinhardtii as efficient bio-system for detoxification of cyanide from the environment especially, from the contaminated water sites.

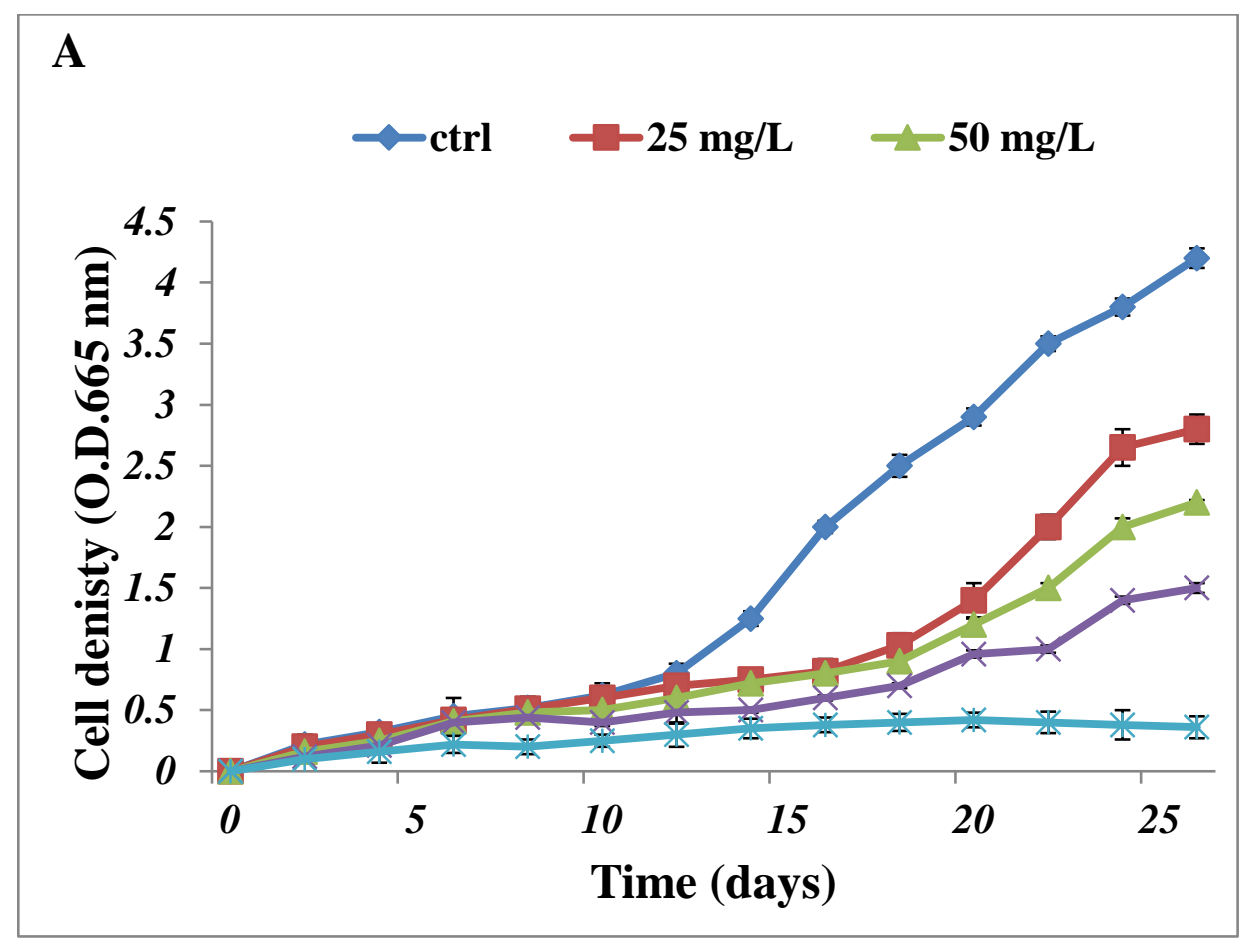




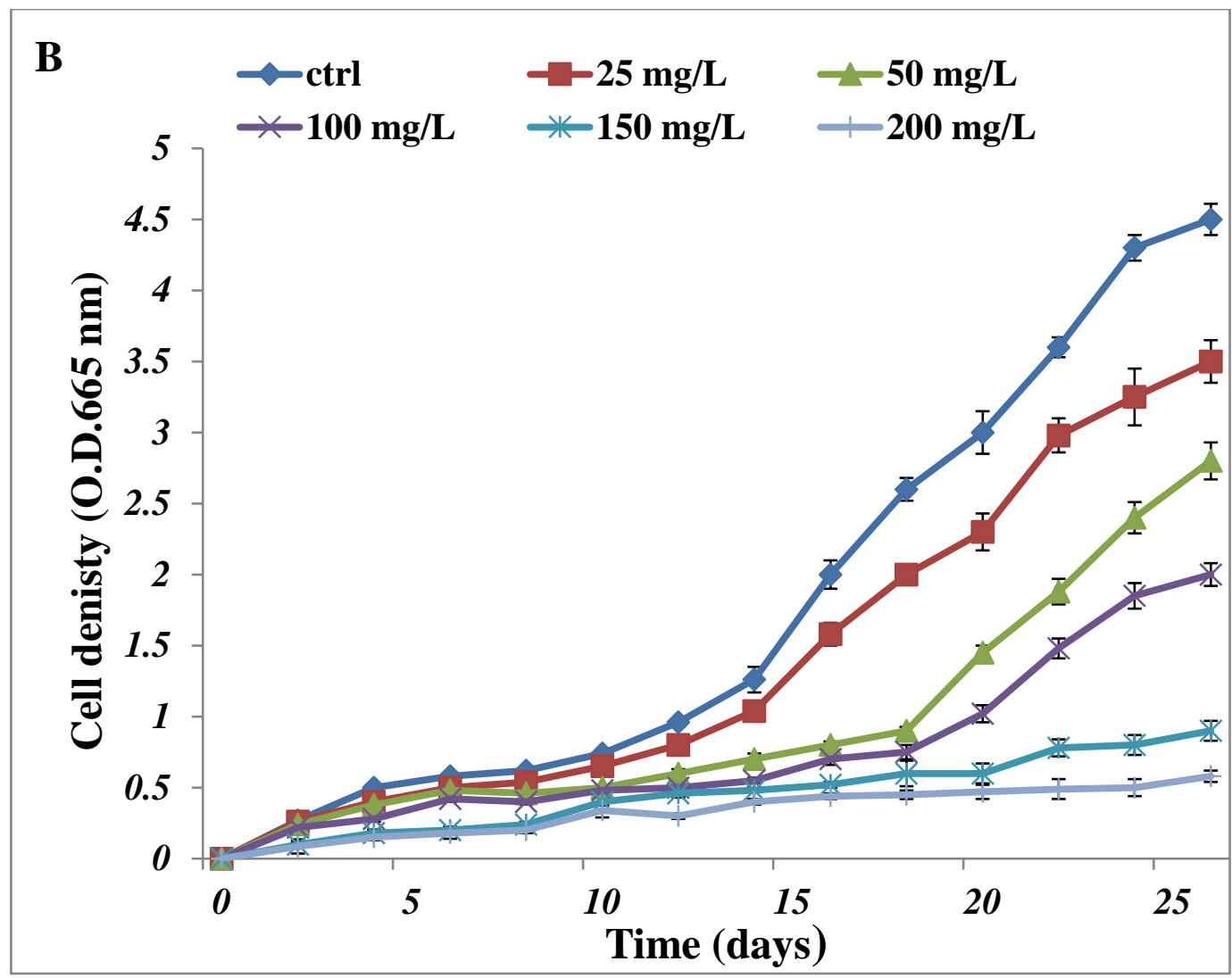

Fig.1: Growth of both (A) wild type and (B) transgenic type of Chlamydomonas reinhardtii in prescence of different concentrations of cyanide.

\subsection{Efficiency of cyanide removal by both wild and transgenic C.reinhardtii.}

Results in Table (1) revealed that transgenic type has promising efficiency to remove potassium cyanide when compared to wild type.

The rate of potassium cyanide removal reaches to $100 \%$ by transgenic type in presence of $25 \mathrm{mg} / \mathrm{l}$ after 24 hours, whereas in case of wild type the rate of removal reaches to $100 \%$ after 48 hours.

In case of application of $50 \mathrm{mg} / \mathrm{l}$ potassium cyanide it is obviously found that transgenic type completely remove this concentration after 36 hours, whereas in case of wild type amount of removal reaches to $35 \mathrm{mg} / \mathrm{l}$ from this concentration after 72 hours.

This mean that the contact time is effective parameter for removal i.e., increasing the rate of removal was parallel to increasing the contact time in case of transgenic type at the relatively low concentration (25 and $50 \mathrm{mg} / \mathrm{l})$. 
Results of relatively high concentration indicate that the wild type can resists the presence of cyanide up to $150 \mathrm{mg} / \mathrm{l}$ and couldn't be able to grow in presence of 200 $\mathrm{mg} / \mathrm{l}$, whereas, transgenic type has the ability to resists cyanide with very low degradation rate.

Table (1): Amount of cyanide removal (mg/l) at different concentrations and times (hours) by wild type and transgenic type of $C$. reinhardtii.

\begin{tabular}{|c|c|c|c|c|c|c|c|c|}
\hline $\begin{array}{l}\text { Time(hour) } \\
\text { Conc.(mg/) }\end{array}$ & $\begin{array}{c}\text { Zero } \\
\mathbf{h}\end{array}$ & $6 \mathrm{~h}$ & $2 \mathrm{~h}$ & $24 \mathrm{~h}$ & $36 \mathrm{~h}$ & $48 \mathrm{~h}$ & $72 \mathrm{~h}$ & $\begin{array}{l}\text { Total of } \\
\text { amount } \\
\text { remova } \\
\text { l (mg/l) }\end{array}$ \\
\hline & \multicolumn{7}{|c|}{ Wild type } & \\
\hline 25 & $\begin{array}{l}0.00 \\
0.00\end{array}$ & $\begin{array}{r}6.69 \\
\pm 0.33\end{array}$ & $\begin{array}{r}5.42 \\
\pm 0.80\end{array}$ & $\begin{array}{r}5.26 \\
\pm 0.36\end{array}$ & $\begin{array}{c}4.36 \\
\pm 0.3 \\
9\end{array}$ & $\begin{array}{r}3.25 \\
\pm 0.00\end{array}$ & $\begin{array}{r}0.02 \\
\pm 0.00\end{array}$ & 25 \\
\hline 50 & $\begin{array}{l}0.00 \\
0.00\end{array}$ & $\begin{array}{r}14.38 \\
\pm 0.32\end{array}$ & $\begin{array}{r}9.37 \\
\pm 0.00\end{array}$ & $\begin{array}{r}6.25 \\
\pm 0.00\end{array}$ & $\begin{array}{c}3.31 \\
\pm 0.3 \\
1\end{array}$ & $\begin{array}{r}0.81 \\
\pm 0.39\end{array}$ & $\begin{array}{r}0.63 \\
\pm 0.38\end{array}$ & 34.75 \\
\hline 100 & $\begin{array}{l}0.00 \\
0.00\end{array}$ & $\begin{array}{r}10.44 \\
\pm 0.00\end{array}$ & $\begin{array}{r}13.44 \\
\pm 0.71\end{array}$ & $\begin{array}{r}7.94 \\
\pm 0.98\end{array}$ & $\begin{array}{c}7.19 \\
\pm 0.2 \\
9\end{array}$ & $\begin{array}{r}0.82 \\
\pm 0.04\end{array}$ & $\begin{array}{r}0.54 \\
\pm 0.13\end{array}$ & 40.37 \\
\hline 150 & $\begin{array}{l}0.00 \\
0.00\end{array}$ & $\begin{array}{r}12.50 \\
\pm 0.53\end{array}$ & $\begin{array}{r}11.88 \\
\pm 0.45\end{array}$ & $\begin{array}{r}6.63 \\
\pm 0.07\end{array}$ & $\begin{array}{c}5.75 \\
\pm 0.7 \\
3\end{array}$ & $\begin{array}{r}0.72 \\
\pm 0.72\end{array}$ & $\begin{array}{r}0.04 \\
\pm 0.0\end{array}$ & 37.55 \\
\hline & \multicolumn{7}{|c|}{ Transgenic type } & \\
\hline
\end{tabular}




\begin{tabular}{|c|c|c|c|c|c|c|c|c|}
\hline $\begin{array}{l}\text { Time(hour) } \\
\text { Conc.(mg/) }\end{array}$ & $\begin{array}{c}\text { Zero } \\
\mathbf{h}\end{array}$ & $6 \mathrm{~h}$ & $2 \mathrm{~h}$ & $24 \mathrm{~h}$ & $36 \mathrm{~h}$ & $48 \mathrm{~h}$ & $72 \mathrm{~h}$ & $\begin{array}{c}\text { Total of } \\
\text { amount } \\
\text { remova } \\
\text { l (mg/l) }\end{array}$ \\
\hline 25 & $\begin{array}{l}0.00 \\
0.00\end{array}$ & $\begin{array}{r}12.58 \\
\pm 0.13\end{array}$ & $\begin{array}{r}10.22 \\
\pm 0.34\end{array}$ & $\begin{array}{r}2.20 \\
\pm 0.23\end{array}$ & $\begin{array}{c}0 \\
\pm 0.0 \\
0\end{array}$ & $\begin{array}{c}0 \\
\pm 0.00\end{array}$ & $\begin{array}{c}0 \\
\pm 0.00\end{array}$ & 25 \\
\hline 50 & $\begin{array}{l}0.00 \\
0.00\end{array}$ & $\begin{array}{r}20.06 \\
\pm 0.57\end{array}$ & $\begin{array}{r}12.1 \\
\pm 0.19\end{array}$ & $\begin{array}{c}9.1 \\
\pm 1.53\end{array}$ & $\begin{array}{c}8.74 \\
\pm 1.8 \\
2\end{array}$ & $\begin{array}{c}0 \\
\pm 0.00\end{array}$ & $\begin{array}{c}0 \\
\pm 0.00\end{array}$ & 50 \\
\hline 100 & $\begin{array}{l}0.00 \\
0.00\end{array}$ & $\begin{array}{r}19.19 \\
\pm 0.69\end{array}$ & $\begin{array}{r}19.06 \\
\pm 1.69\end{array}$ & $\begin{array}{r}13.88 \\
\pm 1.36\end{array}$ & $\begin{array}{c}9.18 \\
\pm 0.8 \\
5\end{array}$ & $\begin{array}{r}5.38 \\
\pm 0.16\end{array}$ & $\begin{array}{r}3.25 \\
\pm 0.46\end{array}$ & 69.94 \\
\hline 150 & $\begin{array}{l}0.00 \\
0.00\end{array}$ & $\begin{array}{r}17.63 \\
\pm 1.21\end{array}$ & $\begin{array}{r}17.13 \\
\pm 2.02\end{array}$ & $\begin{array}{c}8.2 \\
\pm 2.82\end{array}$ & $\begin{array}{c}7.6 \\
\pm 1.4 \\
6\end{array}$ & $\begin{array}{c}2.4 \\
\pm 0.95\end{array}$ & $\begin{array}{r}1.19 \\
\pm 0.56\end{array}$ & 54.15 \\
\hline 200 & $\begin{array}{l}0.00 \\
0.00\end{array}$ & $\begin{array}{r}12.64 \\
\pm 0.00\end{array}$ & $\begin{array}{r}11.33 \\
\pm 0.00\end{array}$ & $\begin{array}{r}9.84 \\
\pm 0.00\end{array}$ & $\begin{array}{c}7.66 \\
\pm 0.0 \\
0\end{array}$ & $\begin{array}{r}0.25 \\
\pm 0.00\end{array}$ & $\begin{array}{r}0.06 \\
\pm 0.00\end{array}$ & 41.92 \\
\hline
\end{tabular}

Data are the avarege of three replicates $\pm \mathrm{SE}, * * * \mathrm{p}<0.001$.

\subsection{Ammonia released by transegenic $C$. reinhardtii under cyanide stress}

Cyanase catalyzes the decomposition of cyanide into $\mathrm{CO}_{2}$ and $\mathrm{NH}_{3}$ in presence of bicarbonate. Therefore, the amount of ammonia released from wild type and transgenic $C$. reinhardtii lines in presence of variable concentrations of cyanide was measured. This assay relies on the inhibition of ammonia fixation/re-fixation in the GS2 (Glutamine synthase2)/Fd-GOGAT (Ferredoxin-dependent Glutamine Oxoglutarate Amino Transferase) cycle in the presence of phosphinotricin. Fresh $C$. 
reinhardtii wild type and transgenic Chlamydomonas reinardtii cells were incubated in medium contaning different concentration of $\mathrm{KCN}$ (i.e., 0.0, 25, 50, 150, and 200 $\mathrm{mg} / \mathrm{l}$ ) and $2 \mathrm{mM} \mathrm{NaHCO} 3$ as described in materials and methods section. Absence of $\mathrm{KCN}$, in control and $\mathrm{NH}_{3}$ release was not particularly evident in both transgenic and wild type control samples. A gradual decrease in the amount of $\mathrm{NH}_{3}$ was observed for wild type $C$. reinhardtii by increasing $\mathrm{KCN}$ concentrations (Inverse relationship). On contrary, significant KCN concentration dependent $(p \leq 0.001)$ increases in the amount of $\mathrm{NH}_{3}$ released was observed for all the two CYN transgenic lines compared to wild type controls (Direct relationship). Again, line Cr.CYN-2 was superior when compared to Cr.CYN-1 Fig.2. The reduction of ammonia release observed for wild type control may be attributed to the limited capacity of the endogenous cyanase to overcome the excess cyanide applied to the reaction mixture [35]. Induction of the cyanase gene transcription in microorganisms can be accomplished with the use of exogenous cyanide [37]. However, induction of cyanase gene transcription is almost absent in plants because endogenous cyanase gene transcription was only observed to be up regulated under salt stress [34, 35].

The results of ammonia release experiment show that CYN transgenic C.reinhardtii can produce more ammonia from exogenously applied cyanide, demonstrating the functioning of the cyanobacterial cyanase enzyme in chlamydomonas reinhardtii. This emphasises the importance of cyanide detoxification using CYN transgenic lines. Also, the result indicated that the nitrogen from ammonia accumulated directly as an intermediate product before nitrate instead of being completely nitrified [38]. Despite this, ammonia accumulation was affected by decreasing cyanide degradation because ammonia inhibits boi-oxidation due to the participation of microbial enzymes in cyanide degradation, nitrification in the treatment system $[39,40]$. However, there was a changing concentration of ammonia in the medium; the high ammonia concentration could inhibit cyanide biodegradation because organisms prefer ammonia rather than cyanide as a nitrogen source, thus reducing cyanide degradation by microbial species [41]. 


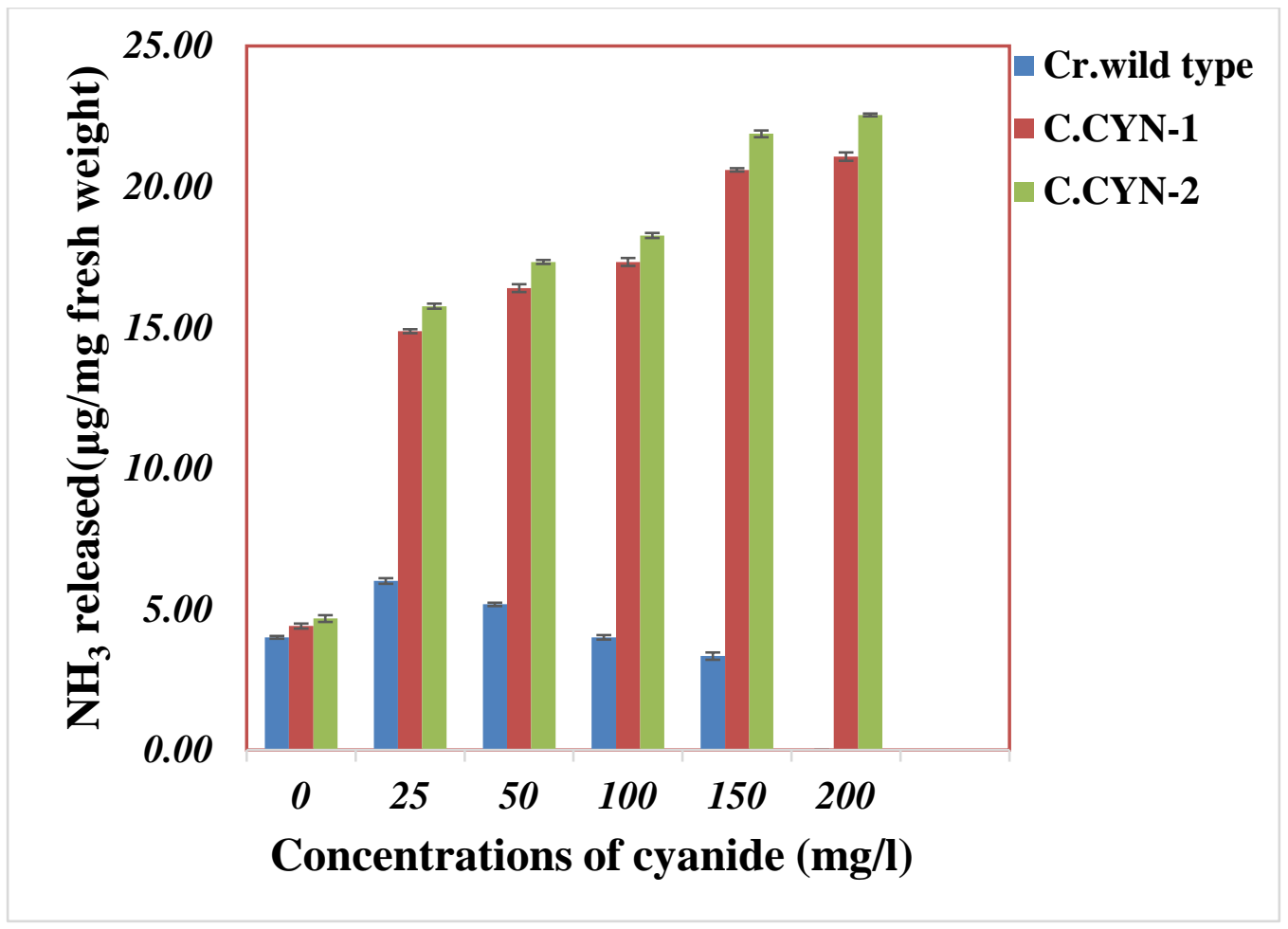

Fig.2: Amount of ammonia released from CYN transgenic and wild type $C$. reinhardtii under differernt concentrations of $\mathrm{KCN}$.

\subsection{Cyanase activity}

Cyanase activity in vitro was also tested in extraction of protein of both wild and transgenic types Table (2). Results revealed that cyanase reachs its maximum activity following the application of $100 \mathrm{mg}^{-1} \mathrm{KCN}$. It reached eight folds more than the corresponding activity in wild extract. Moreover, in general as the concentration increased the activities in both wild type and transgenic type increased up to $50 \mathrm{mg}^{-1}$ followed by sharp decline in the activity of wild extract especially, in presence of relatively high concentrations of cyanide (100 and $150 \mathrm{mg} / \mathrm{l})$. On the other hand, activity in transgenic type showed an obvious increase up to high concentration. Endogenous cyanases and other nitrogen-assimilating enzymes may be responsible for the background activity in wild control $[42,43]$. Consequently, it can be concluded that the prokaryotic cyanase is active in transgenic $C$. reinhardtii lines and help the species to tolerate the toxicity of cyanide. 
Table (2): Cyanase activity as $\mu$ mol ammonia released / $\mathrm{mg}$ protein/ $1 \mathrm{~min}$

\begin{tabular}{|c|c|c|}
\hline \multirow{2}{*}{$\begin{array}{c}\text { Treatment } \\
\mathrm{mg} / \mathrm{l}\end{array}$} & Wild type & Transgenic type \\
\cline { 2 - 3 } & $2.15 \pm 0.11$ & $2.30 \pm 0.15$ \\
\hline 0.00 & $5.16 \pm 0.15$ & $9.11 \pm 0.25$ \\
\hline 25 & $6.63 \pm 0.10$ & $15.60 \pm 0.0$ \\
\hline 50 & $2.30 \pm 0.00$ & $18.70 \pm 1.0$ \\
\hline 100 & $1.16 \pm 0.00$ & $6.11 \pm 0.32$ \\
\hline 150 & & \\
\hline
\end{tabular}

Data are the avarege of three replicates \pm SE

\subsection{Effect of cyanide on chlorophyll a and $b$ of wild and transgenic $C$. reinhardtii at different time.}

Fig.3 and Fig.4 showed that most concentrations of cyanide lead to subsequent inhibition in chlorophyll $\mathrm{a}$ and $\mathrm{b}$ as compared with untreated sample. The least reduction was observed at relatively low concentrations, whereas at higher concentrations, the rate of reduction of chlorophyll a and b content was pronounced, with an obvious dropping of chlorophyll in both types. In the case of wild type, application of higher concentration $(200 \mathrm{mg} / \mathrm{l})$ resulted in complete delitorus with the cells and, finally, complete death. Also, it could be observed that biosynthesis of chlorophyll a as indicated by it's content was increased with increasing the time in case of transgenic especially, at $25 \mathrm{mg} / \mathrm{l}$ but still lower than untreated transgenic one. The previous behaviour was countered at $25 \mathrm{mg} / \mathrm{l}$ treated wild as the time increased. The content of chlorophyll $\mathrm{a}$ and $\mathrm{b}$ increased with maximum production after $72 \mathrm{~h}$. A similar result of reduction was indicated in wild sample as increasing the cyanide concentration and time. The percentage of reduction in chlorophyll a in wild type was $75.82 \%$ but in case of transgenic type was $37.3 \%$. On the other hand, the percentage of reduction in chlorophyll b in wild type was $81.36 \%$ but in case of transgenic type the percentage of reduction in chlorophyll $\mathrm{b}$ reached to $35.75 \%$. The previous reductions were in concomitant with [44] who found that heavy metal $(\mathrm{Cu})$ reduce and 
inhibits pigment production in Scenedesmus quadricauda and similar results was also obtain in case of Scenedesmus obliquus [45]. Also, pigment reduction was reported for Chlorella vulgaris exposed to KCN [46]. Also, similar results were obtained in case of Chlorella vulgaris exposed to $\mathrm{Cr}$ [47] and also in case of exposed to waste water effluents $[48,49,50]$. The prior decline could be explained by the heavy metal counteracting $\mathrm{Fe}$ and $\mathrm{Mg}$ absorption and so inhibiting chlorophyll production [51]. In our study the decrease in $\mathrm{Chl}$. a/Chl. b for wild type $C$. reinhardtii could be due to cyanide-dependent inhibition of enzymes involved in numerous metabolic processes related to pigment production and viability $[52,53]$. These findings suggested that wild-type Chl. $\mathrm{b}$ is more sensitive than transgenic Chl.b. As a result of the oxidation of the methyl group on the ring II, some Chl.a can be changed to Chl.b [54]. These results are matched with [55] who found that the increase of Chlorophyll $a / b$ in Chlorella vulgaris under $0.5 \mathrm{Cd} \mathrm{mg} / \mathrm{l}$. The mitochondrial cytochrome $\mathrm{C}$ oxidase that is actively involved in the respiratory electron transport chain was reported to be inhibited by cyanide and its oxidative product cyanate [56]. Other enzymes such as ribulose- 1,5 bisphosphate carboxylase/oxygenase [57] and enzymes involved in reactive oxygen scavenging [58] are proved to be inhibited by cyanide. Additiionally, cyanide and cyanate are known to inhibit biological processes including respiration, carbon and nitrate assimilation by binding to metalloenzymes [52, 59]. Transgenic Arabidopsis thaliana plants overexpressing the cyanobacterial cyanase enzyme [36] or overexpression the bacterial cyanidase enzyme [60] showed significant increase in chlorophyll a, chlorophyll b, and carotenoids contents compared to control plants under cyanate or cyanide stress respectively. The observed result in this assay indicates that $\mathrm{KCN}$ induced loss of pigmentation was alleviated through over expression of the cyanobacterial enzyme cyanase in C. reinhardtiin cells. 

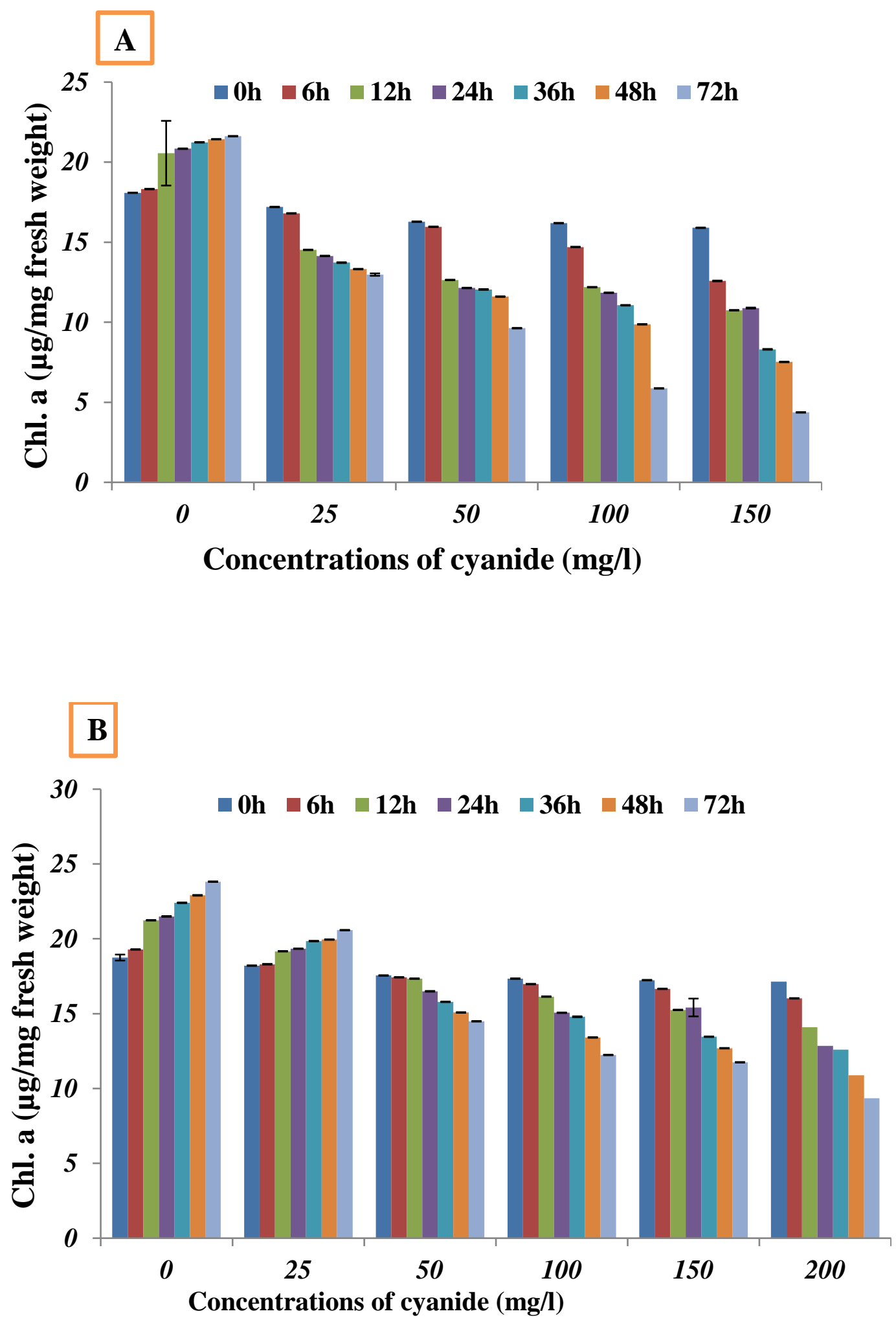

Fig.3: Effect of different concentrations of cyanide on chlorophyll a of both (A) wild type and $(B)$ transgenic type of $C$. reinhardtii at different times. 

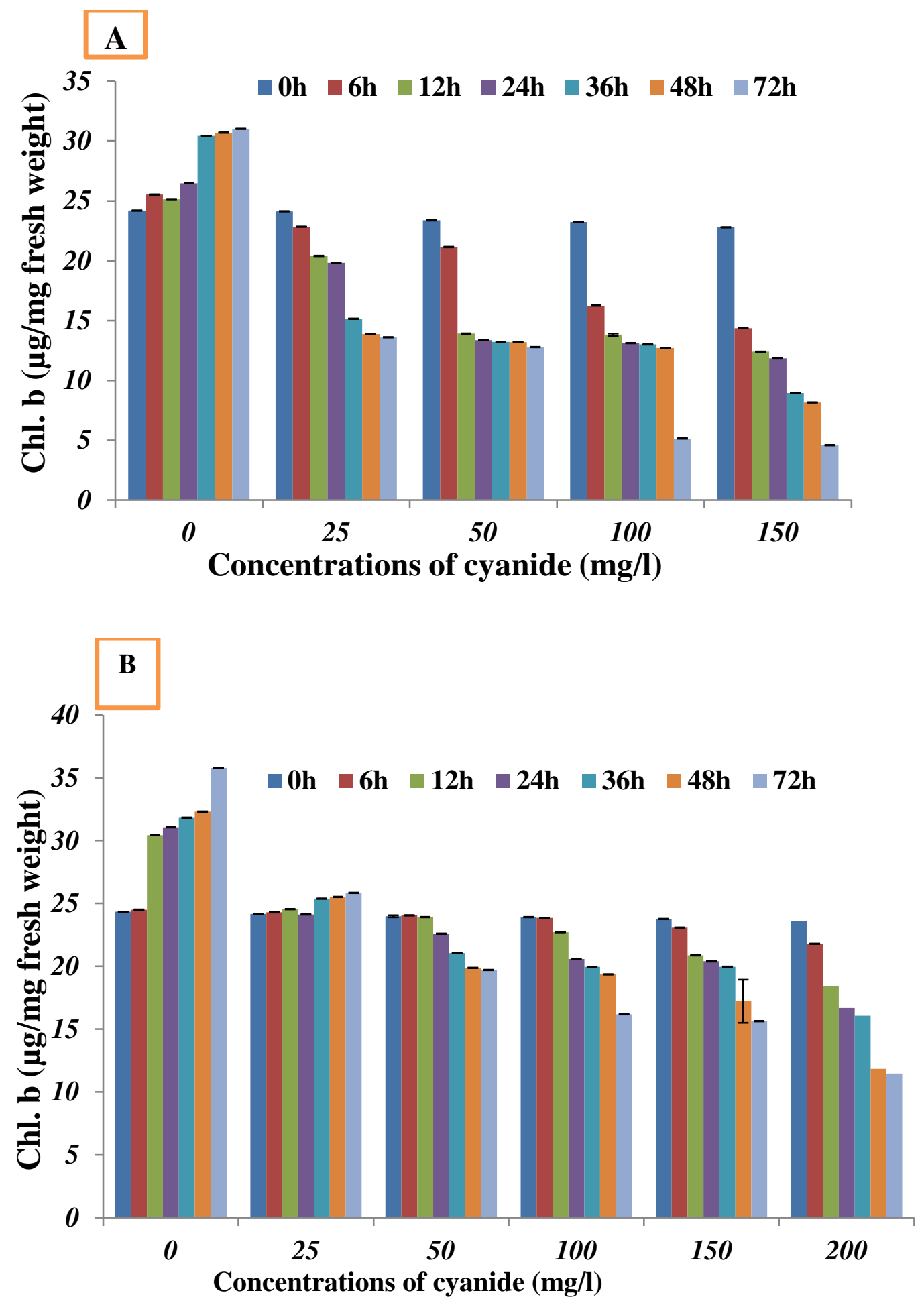

Fig.4: Effect of different concentrations of cyanide on chlorophyll b of both (A) wild type and (B) transgenic type of $C$. reinhardtii at different times. 
3.6 Effeciency of both wild and transgenic genotypesto detoxifying cyanide at different pHs

Fig.5 revealed that the rate of removal gave subsequent increasing as the $\mathrm{pH}$ increased from $\mathrm{pH} 5$ to 11 . The maximum recorded following the application of $\mathrm{pH}$ $10(95.09 \%)$ then decreased to $(90.88 \%)$ at $\mathrm{pH} 11$. In wild type the rate of removal reaches the maximum level at $\mathrm{pH} 9(45.96 \%)$ less than transgenic at $\mathrm{pH} 9(92.96 \%)$. Moreover, the subsequent removal of cyanide by transgenic cells resulted in two folds increase more than the corresponding values in case of wild type. The previous results are in concomitant with the explanation that, microbial activity can reduce cyanide to ammonia, which oxidises to nitrate under aerobic circumstances. With cyanide concentrations up to 200 parts per million, this technique has proven to be effective [61]. He also, demonstrated that the best conditions for cyanide breakdown were 34 ${ }^{\circ} \mathrm{C}, \mathrm{pH} 10.3$, and a glucose content of $0.44(\mathrm{~g} / \mathrm{l})$. Furthermore, cyanide degradation reached a maximum level at 96 percent during the exponential period. Burkholderia cepacia can remove cyanide in a $\mathrm{pH}$ range of 8 to 10 , with the highest cyanide removal (1.85 mg CN. $\mathrm{h}^{-1)}$ occurring at $\mathrm{pH} 10$ [26]. (Under alkaline conditions $(\mathrm{pH}$ 9.2-10.7), Cyanide was metabolised via a cyanide hydratase and amidase route [62]. At $\mathrm{pH}$ of 9.5, cyanide degradation by the strain Pseudomonas pseudoalcaligenes CECT5344 may therefore provide.

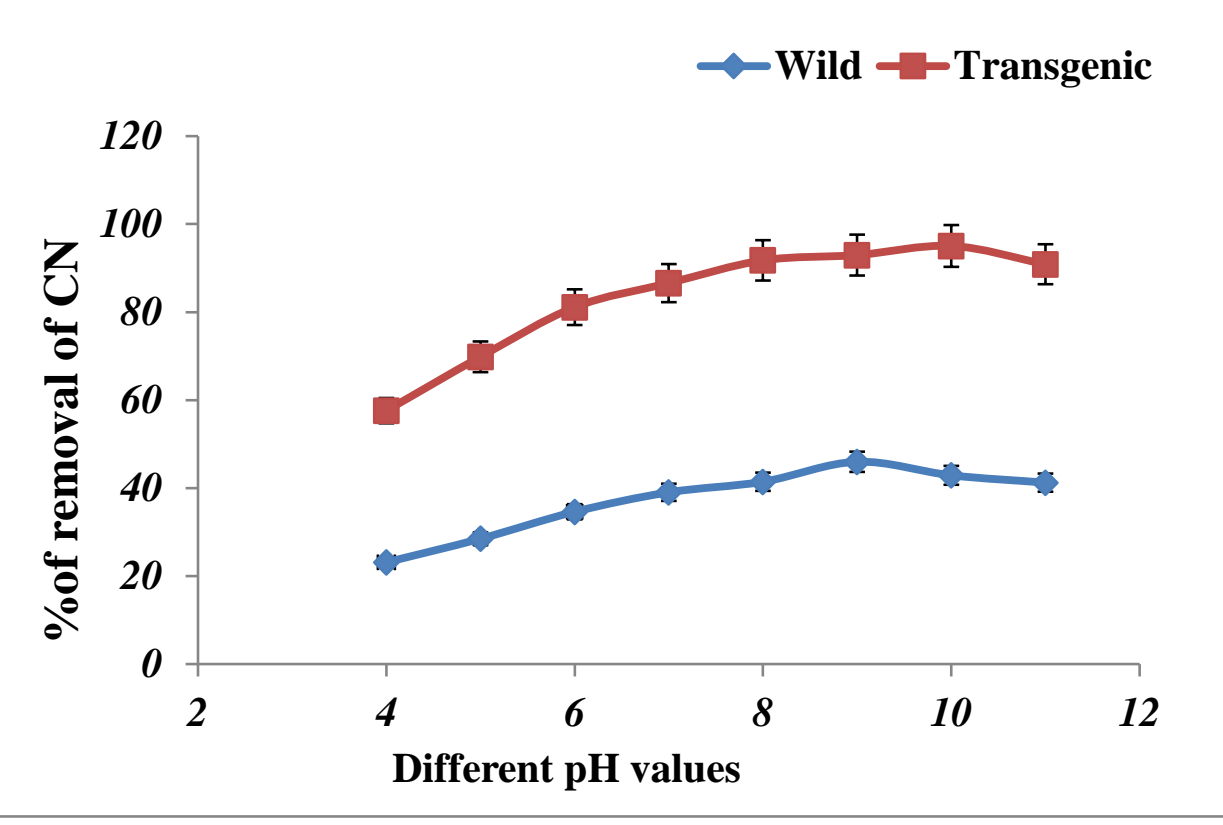

Fig.5: Percentage of cyanide removal by wild and transgenic type of $C$.reinhardtii at different $\mathrm{pH}$ values. 


\section{Conclusion}

The results have indicated a novel mechanism for bioremediation of cyanide toxicity from water using transgenic Chlamydomonas reinharditii alga. Such results confirmed that CYN gene reduce the toxicity of cyanide and this represented in the measured biochemical parameters. Cyanide depletion assays and algal growth showed a significant increase in transgenic type to resist cyanide stress as compared to wild type. The presence of CYN gene has induced a protection response to the biosynthesis of green pigments. Visible phytotoxic symptoms due to cyanide application was only observed in wild type alga. The development of phycoremediation system for the degradation of toxic contaminants in agricultural fields could benefit from transgenic algae detoxifying cyanide. The current results could be applied to other crops in programs aimed at increasing pollution tolerance and limiting contamination in the food supply chain. As a result, the transgenic $C$. reinhardtii strain has shown promise in a wide range of cyanide detoxifying environments.

\section{References}

[1] D.A. Dzombak, R.S. Ghosh, G.M. Wong-Chong, Cyanide in Water and Soil: Chemistry, Risk, and Management, (1st ed.), CRC Press, (2005), London.

[2] J.Baxter, S.P. Cummings, The current and future applications of microorganism in the bioremediation of cyanide contamination, Antonie Van Leeuwenhoek 90: (2006) 1-17.

[3] R.R. Dash, A. Gaur, C. Balomajumder, Cyanide in industrial wastewaters and its removal areview on biotreatment, J .Hazard Mater 163: (2009) 1-11.

[4] N. Dwivedi, C. Balomajumder, P. Mondal, Comparative investigation on the removal of cyanide from aqueous solution using two different bioadsorbents, Water Resoure Indust 15: (2016a) 28-40.

[5] N. Dwivedi, C.B. Majumder, P. Mondal, Bioremoval of cyanide from aqueous solution using Tectona grandis leaves powder: a potential bioadsorbent, Int. J. Environ Technol Manag 19: (2016b) 198-219.

[6] N.Dwivedi and S. Dwivedi 2021 in Sustainable biological approach for removal of cyanide from wastewater of a metal-finishing industry (Membrane-Based Hybrid Process. For Wastewater Treatment, Elsevier) p 463-479.

[7] K. Dong, F.X Wang, Y. Chang, D. Lu, X. Gu, C. Chen, The detoxification and utilization of cyanide tailings: A critical review, J. of Cleaner, Product 302: (2021) 126946.

[8] N. Dwivedi, C.B. Majumder, P. Mondal, Studies of kinetic and equilibrium isotherm models for the sorption of cyanide ion on to almond shell, Res. J. Chem Sc 4: (2014) 20-24. 
[9] N.Gupta, C.B. Majumder, V.K. Agarwal, Enzymatic mechanism and biochemistry for cyanide degradation: a review, J Hazard Mater 176: (2010) 113.

[10] J. Westley, B. Vannesland, E.E. Conn, C.J. Knowles, F. Wissing, Cyanide compounds in Biology, (1981), London: Academic Press Inc 58(1).

[11] K. Hagelstein, The ecotoxicological properties of cyanide, in short course notes on management of cyanide in mining, Australian Centre for Minesite Rehabilitation Research, (1997), Perth, Western Australia.

[12] A. Akcil, T. Mudder, Microbial destruction of cyanide wastes in gold mining process review, Biotechnol Lett 25: (2003) 445-450.

[13] J. Taylor, N. Roney, C. Harper, ATSDR (Agency for Toxic Substances and Disease Registry, Toxicological Profile for Cyanide, (2006), Atlanta, GA: U.S. Department of Health and Human Services. Public Health Service.

[14] B. Latkowska, J. Figa, Cyanide removal from industrial wastewaters, J Environ Stud 16: (2007) 148-152.

[15] F. Gurbuz, H. Ciftci, A. Akcil, Biodegradation of cyanide containing effluents by Scenedesmus obliquus, J Hazard Mater 162: (2009) 74-79.

[16] L. Fairbrother, J. Shapter, J. Brugger, G. Southam, A. Pring, F. Reith, Effect of the cyanide-producing bacterium Chromobacterium violaceum on ultra flat au surfaces, Chem Geol 265: (2009) 3-4.

[17] H.G. Shete, B.P. Kapdnis, Cyanide hydratase production using acclimatized strain of streptomyces phaeovride and its characterization, Int $\mathrm{J}$ Bioassays 8: (2013) 1098-1103.

[18] A.C. Sexton, B.J. Howlett, Characterisation of a cyanide hydratase gene in the phytopathenogenic fungus Leptosphaeria maculans, Mol Genet 263: (2000) 463-470.

[19] WHO, World Health Organization, Fluorine and fluorides, environmental health criteria 36, (1984), Geneva.

[20] M. Nallapan - Maniyam, F. Sjahrir, A. Ibrahim, A.G. Cass, Biodegradation of cyanide by Rhodococcus, UKMP-5 M, Biologia 68: (2013) 177-185.

[21] V.M. Luque-Almagro, M.J. Huertas, M. Martínez-Luque, C. Moreno-Vivián, M.D. Roldán, L.J. García-Gil, F. Castillo, R. Blasco, Bacterial degradation of cyanide and its metal complexes under alkaline conditions, Appl Environ Microbiol 71: (2005) 940-947.

[22] A. Akcil, Destruction of cyanide in gold mill effluents: biological versus chemical treatments, Biotechnol Adv 21: (2003) 501-511.

[23] F. Gurbuz, H. Ciftci, A. Akcil, A.G. Karahan, Microbial detoxification of cyanide solutions: a new biotechnological approach using algae, Hydrometallurgy 72: (2004) 167-176.

[24] M. Mirsanjari, G.S. Ardakani, Study on biological removal of cyanide from artificial sewage and identify resistant microorganisms to cyanide, J. Env. Sci. Tech 22: (2021) 241-250. 
[25] Y. El-Ayouty, M. Ismaiel, A. Al-Badwy, R. Kebeish, "Overexpression of Cyanase in Chlamydomonas reinhardtii: a Promising Approach for Biodegradation of Cyanate in Aquatic Systems", Water Air Soil Pollut 230:123 (2019), https://doi.org/10.1007/s11270-019-4175-0.

[26] D.S. Gorman, R.P. Levine, Cytochrome $\mathrm{f}$ and plastocyanin: their sequence in the photosynthetic electron transport chain of Chlamydomonas reinharditi, Proce Natl Acad Sci USA 54: (1965) 1665-1669.

[27] R.L.G. Robert 1979 Growth measurements, division rate. In: Stein, R.J. (ed) Physiological methods. Culture and growth measurements, Cambridge University Press, 275, p 29-311.

[28] APHA, AWWA, WPCF 1995 Standard Method for the examination of water and wastewater, $19^{\text {th }}$ edition. Washington DC: American Public Health Association.

[29] S. Rasco-Gaunt, A. Riley, P. Lazzeri, P. Barcelo, A facile method for screening for phosphinothricin (PPT)-resistant transgenic wheats, Molec. Breedi 5: (1999) 255-262.

[30] M.M. Bradford, A rapid and sensitive method for the quantitation of microgram quantities of protein utilizing the principle of protein-dye binding, Analytical Biochemistry 72: (1976) 248-254.

[31] P.M. Anderson, Purification and properties of the inducible enzyme cyanase, Biochem19: (1980) 2882-2888.

[32] H. Metzner, H. Rau, H. Senger, Untersuchungen zursynchronisierbarkeit einzelner pigment-mangel mutantenvon Chlorella, Planta 65: (1965) 186-194.

[33] S.W. Jeffrey, G.F. Humphrey, New spectrophotometric equations for determining chlorophylls a, b, c1 and c2 in higher plants, algae and natural phytoplankton, Biochem and Physiolog der Pflanzen 167: (1975) 191-194.

[34] H. Askari, J. Edqvist, M. Hajheidari, M. Kafi, G.H. Salekdeh, Effects of salinity levels on proteome of Suaeda aegyptiaca leaves, Proteomics 6: (2006) 25422554.

[35] D. Qian, L. Jiang, L. Lu, C. Wei, Y. Li, Biochemical and structural properties of cyanases from Arabidopsis thaliana and Oryza sativa, PLoS One 6(3): (2011) e18300.

[36] R. Kebeish, O. Al-Zoubi, Expression of the cyanobacterial enzyme cyanase increases cyanate metabolism and cyanate tolerance in Arabidopsis, Environ. Sci. Pollut Res. Int 12: (2017) 11825-11835.

[37] V.M. Luque-Almagro, M. Víctor, J. María, P. Huertas, P. Lara, M. Sáez, M. Manuel, M.V. Luque-Romero, M.V. Conrado, C. Francisco, R.M. Dolores, B. Rafael, Characterization of the Pseudomonas pseudoalcaligenes CECT5344 cyanase, an enzyme that is not essential for cyanide, Assimilation. Appl. Environ. Microbiol74: (2008) 6280-6288.

[38] Y. Ma, M. Rajkumar, H. Freitas, Improvement of plant growth and nickel uptake by nickel resistant-plant-growth promoting bacteria, J. Hazard Mater 166: (2009) 1154-1161. 
[39] Y.G. Zheng, J. Chen, Z.Q. Liu, M.H. Wu, L.Y. Xing, et al, Isolation, identification and characterization of Bacillus subtilis ZJB-063, a versatile nitrile-converting bacterium, Appl Microbiol Biotechnol, 77: (2008) 985-993.

[40] D. Naveen, B. Chandrajit, M. Prasenjit, Biological treatment of cyanide containing waste water, Res. J .Chem .Sci 1: (2011) 15-21.

[41] L. Mekuto, V.A. Jackson, S.K.O. Ntwampe, Biodegradation of free cyanide using Bacillus sp. Consortium dominated by Bacillus safensis, licheniformis and tequilensis strains: A bioprocess supported solely with whey, $\mathbf{J}$ .Bioremed.Biodeg (18): (2013) 2-7.

[42] P.M. Anderson, R.M. Little, Kinetic properties of cyanase, Biochem 25: (1986) 1621-1626.

[43] M. Aichi, I. Nishida, T. Omata, Molecular cloning and characterization of a cDNA encoding cyanase from Arabidopsis thaliana, Pla.and Cell Physiol 39: (1998) S135-S135.

[44] J. Kováčik, B. Klejdus, J. Hedbavny, M. Bačkor, Effect of copper and salicylic acid on phenolic metabolites and free amino acids in Scenedesmus quadricauda (Chlorophyceae), Plant Sci, 178: (2010) 307-311.

[45] H. Chen, J. Chen, Y. Guo, Y. Wen, J. Liu, W. Liu, Evaluation of the role of the glutathione redox cycle in $\mathrm{Cu}$ (II) toxicity to green algae by a chiral perturbation approach, Aquat. Toxicol 120-121: (2012) 19-26.

[46] Q. Liu, G. Zhang, J. Ding, H. Zou, H. Shi, C. Huang, Evaluation of the Removal of Potassium Cyanide and its Toxicity in Green Algae (Chlorella vulgaris), Bull Environ Contam Toxicol 100: (2018) 228-233.

[47] U.V Rai, N.K. Singh, A.K. Upadhyay, S. Verma, Chromate tolerance and accumulation in Chlorella vulgaris L.: role of antioxidant enzymes and biochemical changes in detoxification of metals, Bioresoure Technol 136: (2013) 604-609.

[48] W.S. Abou El- Kheir, A.H. Farag, S. AbdelKader, Production of Microalgae Biomass Using Vinasse as Cultivation Medium, J. of scientific research in science 32: (2015) 78-106.

[49] F. Abdelbaset, W.S. Abou El- Kheir, A.H. Farag, F.A. Mourad, N.M. Nasef, Extraction of Sulphated Polysaccharides (SPs) from Different Species of Marine Macroalgae and Studying their Role as Natural Anticoagulant, J. of scientific research in science 33: (2016) 134-159.

[50] H.A. Musbah, W.S. Abouelkhair, S.A. Yousef, E.E. Moustafa, A.M. Hasan, Screening of Antifungal Activities of Five Algal Crude Extracts, J. of scientific research in science 36: (2019) 318-338.

[51] I.V. Seregin, A.D. Kozhevnikova, Physiological role of nickel and its toxic effects on higher plants, Russ. J. Plant. Physiol 53: (2006) 257 - 277.

[52] L.P. Solomonson 1981 Cyanide as a metabolic inhibitor in: B.Vennesland, E.E. Conn, C.J. Knowles, J. Westley, F. Wissing, (ed) Cyanide in biology (Academic Press, London) p11-28. 
[53] V.D. Samuilov, D.B. Kiselevsky, S.V. Sinitsyn, A.A. Shestak, E.M. Lagunova, A.V. Nesov, $\mathrm{H}_{2} \mathrm{O}_{2}$ intensifies $\mathrm{CN}^{-}$induced apoptosis in pea leaves, Biochemistry-Moscow 71: (2006) 384-394.

[54] M.K. Chettri, C.M. Cook, E. Vardaka, T. Sawidis, T. Lanaras, The effect of Cu, $\mathrm{Zn}$ and $\mathrm{Pb}$ on the chlorophyll content of the lichen Cladonia convoluta and Cladonia rangiformis, Environ Exp Bot 39: (1998) 1-10.

[55] J. Cheng, H. Qiu, Z. Chang, Z. Jiang, W. Yin, The effect of cadmium on the growth and antioxidant response for freshwater algae Chlorella vulgaris', Springer Plus 5:(2016) 1290-1298.

[56] J.L. Way, Cyanide intoxication and its mechanism of antagonism, Annu. Rev. Pharmacol. Toxicol 24: (1984) 451-481.

[57] M.W. Wishnik, M.D. Lane, Inhibition of ribulose diphosphate carboxylase by cyanide, J. Biol Chem 244: (1969) 55-59.

[58] T. Karuppanapandian, J.H. Moon, C. Kim, K. Manoharan, W. Kim, Reactive oxygen species in plants: their generation, signal transduction, and scavenging mechanisms, Australian J. Crop Sci 5: (2011) 709-725.

[59] H.B. Leavesley, L. Li, K. Prabhakaran, J.L. Borowitz, G.E. Isom, Interaction of cyanide and nitric oxide with cytochrome c oxidase: Implications for acute cyanide toxicity, Toxicol Sci 101: (2008) 101-111.

[60] R. Kebeish, M. Aboelmy, A. El-Naggar, Y. El-Ayouty, C. Peterhansel, Simultaneous overexpression of cyanidase and formate dehydrogenase in Arabidopsis thaliana chloroplasts enhanced cyanide metabolism and cyanide tolerance, Environ. Exp. Bot 110: (2015) 19-26.

[61] S. Mirizadeh, S. Yaghmaei, N.Z. Ghobadi, Biodegradation of cyanide by a new isolated strain under alkaline conditions and optimization by response surface methodology (RSM), J of environ Heath Sci engineer 12, 85: (2014).

[62] M.J. Huertas, L.P. Sáez, M.D. Roldán, V.M. Luque-Almagro, M. MartínezLuque, R. Blascoc, F. Castillo, G.G. Moreno-Vivián, Alkaline cyanide degradation by Pseudomonas pseudoalcaligenes CECT5344 in a batch reactor influence of pH, J. Hazard Mater 179: (2010) 72-78. 


\section{الملخص العربي}

\section{كفاءة طحلب الكلاميدوموناس المعدل وراثيا في ازالة سمية مركب السيانيا}

رشا عابد الجمال*1 ياسين محمود العيوطي² ـ شيماء سلمي صبيح1 ـ وفاء صبحى أبوالخير1ــ علية أنور

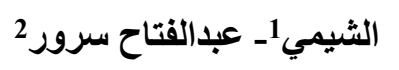

1- قسم علم النبات، كلية البنات للآداب و العلوم والتربية، جامعة عين شمس ، القاهرة، جمهورية مصر العربية. 2- قسم علم النبات، كلية العلوم، جامعة الزقازيق ، الثرقية، جمهورية مصر العربية. الملخص العربي

تزايدت في الآونه الأخيره سرعة تطوير تقنيات جديدة لمعالجة النفايات الصناعية والخطرة،وذلك من خلال

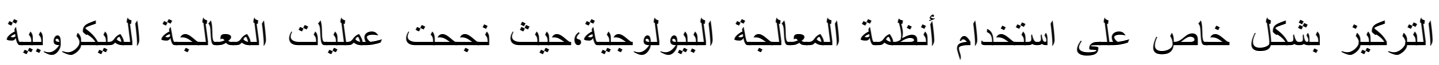
(الهو ائية واللاهو ائية) في تحليل و / أو إزالة المركبات العضوية وغير العضوية والعناصر الثقيلة. ويعتبر السيانيد من أكثر هذه المركبات استخداما، وهي من المو اد الكيميائية السامة المعروفة التي يتم إنتاجها من خلال

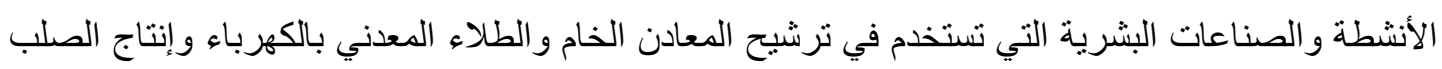
و البلاستيك و الألياف الصناعية.

و أجريت الدراسة بنمو السلالة المعدلة وراثيا من طحلب الكلاميدوموناس و الغير معدلة تحت تركيزات مختلفة من مركب السيانيد (25 ، 50 ، 100 ، 150 و 200ملليجرام /لتر) أظهرت الدراسة قدرة السلالات المعدلة وندات ور اثياعلي النمو في التركيزات العالية مقارنة بالسلالة الغير معدلة خاصة عند تركيزي 150 وتركيز 200 ملليجر ام/لتر.

و عند معاملة الطحالب (المعدلة وراثيا و الغير معدلة) بتركيزات مختلفة من السيانيد (25 ، 50 ، 100 ، 150

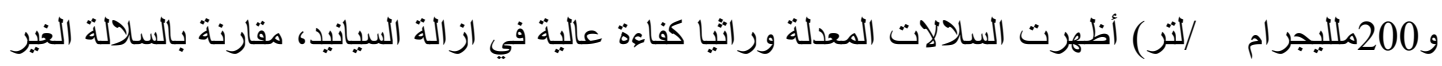

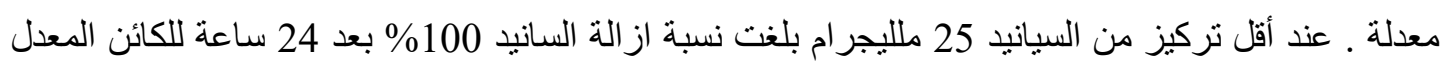
ور اثيا بينما الكائن الغير معدل ور اثيا بعد 48 ساعة.عند التعرض للتركيز العالي من السيانيد 200 ملليجرام لم لم لماتيل يستطع الكائن الغير معدل ور اثيا النمو

كما أظهرت الدراسة قدرة السلالات المعدلة ور اثيا إنتاجا عاليا من الأمونيا بالاضافة الي انخفاض في محتوى

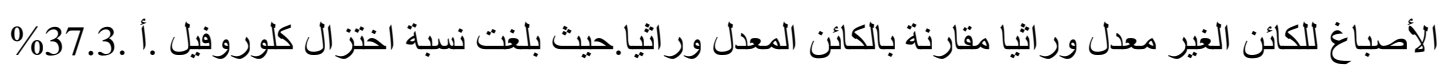
في السلالة المحورة ور اثيا مقارنة ب 75.82\% في السلالة الغير محورة ور اثيا.و أيضا قد بلغت نسبة اختز ال كلوروفيل. ب 35.75 \% في السلالة المحورة ور اثبا مقارنة ب 75.82\% في السلالة الغير محورة ور اثيا. 